\title{
„Ki fizeti a masszázst?" \\ Fürdőgyógyászati szolgáltatások közfinanszírozása Európa egyes országaiban és Magyarországon ${ }^{1}$
}

\author{
Szerzők: Hinek Mátyás² - Dózsa Csaba³ - Mató-Juhász Annamária ${ }^{4}$ - Juhász Szabolcs ${ }^{5}$
}

Jelen tanulmány a fürdőgyógyászati szolgáltatások közfinanszírozásának rendszerét vizsgálja Európa öt országában és Magyarországon. Ismertetjük és összehasonlítjuk a fürdőgyógyászati kezelések igénybevételének föbb szabályait az egyes országokban, illetve áttekintjük, hogy a biztosítók milyen jellegú ellátásokat, milyen szabályok alapján, milyen mértékben finanszíroznak. A nyugat-európai rendszerekkel összevetve részleteiben tekintjük át a magyar finanszírozási szabályokat. Legfontosabb konklúziónk, hogy jól múködő közfinanszírozott egészségügyi ellátórendszer nélkül nincs versenyképes egészségturisztikai kinálat.

Kulcsszavak: egészségturizmus, orvosi turizmus, fürdőgyógyászati ellátások, egészségügyi finanszírozás.

\section{Bevezetés}

Az egészségügyi (orvosi vagy medical) turizmus az egészségturizmusnak az az ága, ahol az emberek helyváltoztatása, utazása kifejezetten gyógykezelési, rehabilitációs célból történik. Ehhez valamilyen mértékben turisztikai szolgáltatások igénybe vétele is társul (SMITH-PUCZKÓ 2009).

Az orvosi turizmus niche jellegú turizmus, amelyet az elérhetô minőségi szolgáltatások mellett az árak (költségek) különbözősége generál. Az elmúlt két évtizedben az egészségügyben bekövetkező költségrobbanás a pácienseket (és nem egyszer a biztosítókat is) az olcsóbb igénybevételek felé tereli, különösen, ha a beteg otthoni egészségbiztosítása nem finanszíroz bizonyos kezeléseket (például fogászat, plasztikai sebészet), ha túl hosszúak a várólisták (lásd például Nagy-Britanniában egyes sebészeti beavatkozásokat), vagy ha külföldön jobb minőségú szolgáltatásokat lehet igénybe venni. Az orvosi turizmus egyik legnagyobb desztinációja Ázsia (CONELL 2006).

\footnotetext{
A tanulmány a „Fürdőgyógyászati szolgáltatások finanszírozási kérdéseinek vizsgálata a hazai gyógyfürdőkben” című, a Magyar Turisztika Ügynökség megbízásából készült elemzés és javaslattevő tanulmány alapján készült.

2 főiskolai tanár, Budapesti Metropolitan Egyetem, mhinek@metropolitan.hu 3 egyetemi docens, Miskolci Egyetem, efkdozsa@uni-miskolc.hu ${ }^{4}$ egyetemi tanársegéd, Miskolci Egyetem, efkegtur@uni-miskolc.hu 'igazgató, Magyar Turisztikai Ügynökség, Turizmus Szakmai Igazgatóság, Szabolcs.Juhasz@mtu.gov.hu
}

Számos ország, köztük Kína, Kuba, Magyarország, India, Thaiföld, Malajzia és Szingapúr támogatja az orvosi turizmust, és versenyez az orvosi turizmusban realizálható jövedelemért, míg több fejlett országban kínálnak olyan réspiaci egészségügyi szolgáltatásokat, amelyek az orvosi turizmus számára is vonzóak (HALL 2012).

Magyarország termál- és gyógyvízkészlete kiemelkedő, az erre épülő infrastruktúra és szolgáltatások fejlesztése az ezredforduló óta a gazdaságés turizmusfejlesztés egyik kitüntetett területe. A gyógy- és termálturizmus fejlesztésével párhuzamosan az egészségturisztikai kutatások körében is felfutás volt megfigyelhetô. SMITH és PUCZKÓ (2009) összefoglaló jellegú kézikönyvükben globális áttekintést adtak az egészségturizmus fejlődéstörténetéről, keresleti és kínálati trendjeiről, valamint a gyógy- és wellnessturizmusban alkalmazható menedzsment- és marketingmódszerekrôl. Más szerzők az egészségturizmus és a fejlesztéspolitika kapcsolatát vizsgálták (JANDALA et al. 2010), illetve számos kutatás elemezte az egészségturizmus különféle területi vonatkozásait (lásd például NAGY-SZÉP 2011). MICHALKÓ és RÁTZ (2011) a területi összefüggéseken túl az egészségturizmus életminőségre gyakorolt hatását és egyes speciális vonatkozásait is áttekintette.

Ezeknek a vizsgálatoknak jellemzően nem volt tárgya sem a kereslet - ezen belül a gyógyfürdőkezelések iránti kereslet elemzése -, sem az ellátások közfinanszírozásának kérdései. Részben azért, mert egy ilyen jellegú vizsgálat nem kifejezetten a turizmus oldaláról közelíti meg az egészségturizmust, hanem az egészségügy finanszírozása 
irányából, mivel a kezelések nagyobb részét állami egészségbiztosítási támogatással vehetik igénybe a betegek, akikre a turizmuskutatás nem tekint turistaként, különösen akkor, ha az igénybevevők belföldiek. Amikor egy beutalóval rendelkező beteg egyénileg vagy csoportban Hajdúszoboszlóra vagy Hévízre érkezik azért, hogy természetes gyógytényezókre épülő balneoterápiás kezeléseket vegyen igénybe egészségi állapotának javítására, valószínúleg maga sem turistaként tekint magára. Azonban, ha utazik, tartózkodik, és ezzel összefüggésben kapcsolódó szolgáltatásokat vesz igénybe, gyakorlatilag belföldi egészségügyi (orvosi/medical) turistává válik.

A magyar gyógyfürdôk és egyéb fürdőgyógyászati szolgáltatók a balneoterápiás és fizikoterápiás gyógyszolgáltatásaik többségét nem piaci alapon kínálják, hanem a beutalóval, azaz az Egészségbiztosítási Alap támogatásával érkező betegeknek nyújtják. Emiatt a közfinanszírozás kritikus fontosságú a fürdőgyógyászatok fenntarthatósága szempontjából. Ezzel párhuzamosan egy speciális egészségturisztikai szegmensről is beszélhetünk, azokról az emberekrôl akiket sok tekintetben beutalóturistáknak nevezhetünk.

A gyógyfürdók fürdógyógyászati kínálata az egészségturisztikai kínálat gerincét jelenti, amelyre az elmúlt évtizedekben részben kihasználatlan potenciálként tekintettek mind a turisztikai, mind az egészségügyi szakemberek. Sajnos ez a potenciál azóta sem megfelelóen kihasznált, sőt az igénybevételek - beleértve a közfinanszírozott és a piaci alapon történó igénybevételeket - stagnálnak.

KINCSES (2010) az évtized elején körvonalazta, hogy a fürdőgyógyászati szolgáltatások és az egészségturizmus egyéb ágazatai milyen kihívásokkal küzdenek Magyarországon. Ugyanebben az évben jelent meg a Magyar Fürdószövetség helyzetértékelése és javaslatai a magyar egészségturizmus versenyképességének javítására. A finanszírozás elégtelensége mellett a helyzetértékelés rámutatott a szabályozási környezet elavultságára és a gyógyszolgáltatások tudományos háttérének hiányára. Az azóta eltelt 7-8 évben sajnos sem a finanszírozás, sem a szabályozási háttér nem változott érdemben.

Jelen tanulmány áttekintést nyújt arról, hogy Európa egyes országaiban és Magyarországon hogyan alakul a fürdőgyógyászati szolgáltatások közfinanszírozása, illetve ismerteti az igénybevételek fontosabb szabályait. A rendszerek sajátosságainak és különbségeinek elemzésével rámutatunk azokra a lehetőségekre, amelyeket érdemes figyelembe venni a magyar közfinanszírozási rendszer fejlesztése során.
$\mathrm{Az}$ európai finanszírozási modelleket, valamint a hazai egészségügyi finanszírozás sajátosságait interneten elérhetó szekunder források alapján tanulmányoztuk. Elemzésünkhöz elsôsorban a Nemzeti Egészségbiztosítási Alapkezeló (NEAK) fürdőgyógyászati szolgáltatásokkal kapcsolatos információit használtuk fel. A másodlagos adatok kiegészítéseként a vezetó vidéki gyógyfürdők körében interjúsorozatot, illetve workshopokat folytattunk le.

\section{A fürdógyógyászati szolgáltatások közfinanszírozásának rendszere Európa egyes országaiban}

Az elemzésbe öt országot, Ausztriát, Csehországot, Franciaországot, Németországot és Romániát vontuk be. Minden országban kezeléssorozatként (kúraként) értelmezik a gyógyfürdőkben igénybe vehetó ellátásokat, ahol a kúracsomag természetes gyógytényezőkre épüló és ezekhez kapcsolódó, fóképp fizikoterápiás kezeléseket tartalmaz. A konkrét kezeléstípusok a magyarhoz hasonlóak, de előfordul néhány, a magyar orvosi gyakorlatban nem alkalmazott kezelés is (például gyógyvizes ivókúra, inhaláció).

\subsection{NÉMETORSZÁG}

Németországban a kezelóorvos javasolja az ellátás módját és formáját (megelőzés vagy rehabilitáció, járó- vagy fekvőbeteg ellátás). Az orvos a kórtörténet ismeretében ítéli meg, hogy várhatóan mely kezelések, mely gyógyfürdőben biztosítják a legjobb eredményt.

A fürdókúra igénybevételéhez a beteg és orvosa az egészség- vagy nyugdíjbiztosítóhoz fordul támogatási kérelemével. A biztosító döntése az orvosi dokumentumokon alapul, ha szükséges, további orvosi vizsgálat is elrendelhető. Ha kivizsgálás nélkül utasítják el a kérelmet, a döntés megfellebbezhetó.

A kúra lehet ambuláns (járóbeteg) jellegú, amely hasonlít a magyar rendszerben receptre felírt fürdôgyógyászati kezelésekhez. Az ambuláns kúra igénybevételére jogosító vény kiváltásának díja 10 euró. A kúra során az egészségbiztosítás az orvosi vizsgálatok 100\%-át, míg a kezelések költségének 90\%-át fedezi. Az így finanszírozott preventív vagy rehabilitációs fürdókúrák költségeihez a biztosító maximum 16 euró/kúranap úgynevezett flat rate hozzájárulást is fizet. A három-, illetve négyévente egyszer igényelhető támogatott kúra maximális hossza 3 hét.

Az úgynevezett kompakt kúra a járóbeteg-ellátás speciális formája. A kúra bentlakásos. A beteg az 
állapotától függően választhat a különböző gyógyfürdők (szolgáltatók) között, és azt is eldöntheti, hogy panzióban, szállodában vagy klinikán kívánja-e igénybe venni a kúrát. Ha magasabb minőségú szolgáltatást igényel annál, mint amit a biztosító ajánl, a többletköltséget viselnie kell. A kezelés csoportosan, egyidejúleg legfeljebb 15 beteggel történik, holisztikus megközelítéssel, amely során több módszert alkalmaznak, egészségnevelést, megelőző intézkedéseket, fizikoterápiát (például víz alatti torna, kardioedzések), balneo- és hidroterápiákat (például iszap- és sófürdők, masszázs, ivókúrák), valamint táplálkozási terápiákat. A kúrák jellemzően 21 naposak, a kezelések és az orvos költségeit az egészség- vagy nyugdíjbiztosítás teljesen fedezi, a beteg napi 10 euró önrészt fizet. Kompakt kúrát négyévente egyszer támogat az egészség- vagy nyugdíjbiztosító.

Az egészségbiztosítási pénztár klinikán, szanatóriumban vagy rehabilitációs létesítményben szállással és étkezéssel fekvőbeteg-ellátást is biztosithat. Ez hasonló a magyar fürdőkórházi ellátásokhoz.

Végül, de nem utolsó sorban, speciális kúrákat jelentenek az anya/apa-gyermek ellátások. Ennek során a szülők (főként az anya) gyógykezelését az Elly-Heuss-Knapp Alapítvány támogatja. Az ellátás lehet prevenciós vagy rehabilitációs jellegú, például a szülői fáradtság csökkentése, vagy kialakult betegségek esetében a tünetek enyhítése. ${ }^{6}$

\subsection{FRANCIAORSZÁG}

A francia rendszerben 12 terápiás irányhoz (például légzőszervi, mozgásszervi, neurológiai, bőrgyógyászati megbetegedések) különböző tartalmú, előírt kúracsomagok tartoznak. A francia gyógyfürdők ezekre a terápiás orientációkra szakosodnak. Gyógyfürdőkúra igénybevétele Franciaországban a következőképpen történik:

- A kezeléseket orvosnak kell felírnia, aki javaslatot tehet arra is, hogy melyik gyógyfürdőben történjen a kezelés. A támogatási kérelemben az orvos jelöli meg a terápiás orientációt.

- Az egészégbiztosítási pénztár két- vagy háromkomponensú támogatást nyújt. Az elsó komponens az orvosi vizsgálatok támogatása a gyógyfürdóben, a második az igénybe vett kezelések támogatása, míg a harmadik az utazás és a tartózkodás költségeinek megtérítése a beteg jövedelmi viszonyai alapján. Ha a pénztár a kérelmet elutasítja, fellebbezés nyújtható be.

- Egy naptári évben egy gyógyfürdő-kezelés-

\footnotetext{
${ }^{6}$ Deutscher Heilbäderverband: Ihr Weg zur Kur. https://www.deutscher-he-
} ilbaederverband.de/die-kur/kurantrag/, Letöltve: 2018. augusztus 12. re jogosult a beteg, további kúra csak alapos és megfelelően indokolt orvosi szakvélemény után írható fel.

- A gyógykezelés időtartama 18 nap, 6 napos ciklusokban, egy-egy nap szünettel, összesen tehát 21 nap.

Az általános rendszer szerint az egészségbiztosítási alapok az ellátás díjának egy részét térítik, a fennmaradó részt a beteg vagy a magánbiztosítója fizeti (1. táblázat).

\section{1. táblázat}

\section{A francia biztosítók által nyújtott támogatások mértéke a fürdőgyógyászati ellátásokban (részlet)}

\begin{tabular}{|c|c|c|c|}
\hline $\begin{array}{c}\text { Termálkúrák } \\
\text { finanszirozási } \\
\text { mértéke }\end{array}$ & $\begin{array}{c}\text { Általános } \\
\text { eset }\end{array}$ & $\begin{array}{c}\text { Elzász- } \\
\text { Moselle- } \\
\text { régió(1) }\end{array}$ & $\begin{array}{c}\text { Az FSV } \\
\text { vagy ASPA } \\
\text { kedvezmé- } \\
\text { nyezettek(2) }\end{array}$ \\
\hline $\begin{array}{c}\text { Orvosi díjak } \\
\text { orvosi felügye- } \\
\text { leti csomag, kie- } \\
\text { gészítô orvosi } \\
\text { ellátás) }\end{array}$ & $70 \%$ & $90 \%$ & $80 \%$ \\
\hline $\begin{array}{c}\text { Hidroterápiás } \\
\text { díjak }\end{array}$ & $65 \%$ & $90 \%$ & $80 \%$ \\
\hline $\begin{array}{c}\text { Szállás és uta- } \\
\text { zási költségek }\end{array}$ & $65 \%$ & $65 \%$ & $80 \%$ \\
\hline $\begin{array}{c}\text { SPA kezelés } \\
\text { (kórházi keze- } \\
\text { lésként) }\end{array}$ & $80 \%$ & $100 \%$ & $100 \%$ \\
\hline
\end{tabular}

(1) Az Elzász-Moselle régió helyi rendszerébe tartozó biztosítottak esetében. (2) A különleges öregségi nyugdíjalap (FSV) vagy az időskorú szolidaritási támogatás (ASPA) kiegészítő juttatására jogosult biztosítottak esetében. Forrás: La Médecine Thermale, efficace, pour longtemps. Les stations thermales françaises, Edition 2017.

\subsection{CSEHORSZÁG}

Csehországban a fürdőgyógyászatra vonatkozó szabályozás 11 nagy betegségcsoport (onkológiai megbetegedések, keringési rendszer betegségei, az emésztôrendszer betegségei, anyagcsere-rendellenességek, mozgásszervi megbetegedések stb.) alapján határozza meg a terápiákat, illetve azt, hogy a gyógyfürdők mely betegségcsoportok ellátására nyújtanak kezeléseket.

A gyógyfürdőellátásokat az egészségügyi ellátórendszer finanszírozza. A beteg és orvosa által kitöltött támogatási kérelmet a biztosító hagyja jóvá, egyben jelzi a gyógyfürdő számára, hogy beteget kíván küldeni. A beteggel a gyógyfürdő veszi fel a kapcsolatot. Az egészségbiztosító az alábbi ellátásokat finanszírozhatja: 
- Komplex fürdóellátás (KLP). Akkor vehető igénybe, ha a beteg munkaképtelen, az ellátást az engedélyezéstől számított 3 hónapon belül meg kell kezdeni. Az ellátás a kezeléseket, az étkezést, valamint a szállást (2 ágyas szobában) fedezi, és hozzájárul a beteget kísérô személy költségeihez. Az ellátásért 70 évnél fiatalabb páciensek 15 cseh korona/fó/éjszaka gyógyvízdíjat kötelesek fizetni. A teljes kúra 14 vagy 21 napos, ami indokolt esetben meghosszabbítható.

- Hozzájárulás a fürdôellátáshoz (PLP). A biztosító csak a kezeléseket támogatja, a szállás és az étkezés a beteget terheli. A teljes kúra hossza megegyezik a KLP ellátással. A kezelés időszakában az ellátott nem munkaképtelen.

- Ambuláns, járóbeteg fizikoterápiás rehabilitáció (FT). Az ellátásra az orvostól kap beutalót a beteg, melyben a kezelések jellege, száma és időtartama is szerepel (például csoportos víz alatti gyógytorna, elektroterápia). A fürdők a beutalt betegeket ütemezetten fogadják.

- Posztoperatív rehabilitáció. Az ellátás célja a mútét utáni regenerálódás, amelyre 7-10 nappal a mútét után kerül sor, így a beteg a kórházból kerül a gyógyfürdőbe. A tartózkodás időtartama 29 nap/28 éjszaka.?

\subsection{AUSZTRIA}

Ausztriában a fürdőgyógyászati szolgáltatások szintén kétféle formában vehetők igénybe. A járóbeteg-ellátásában szakorvos, esetleg házorvos rendeli el a kezeléseket, amelyeket a (fürdő)szolgáltatók szakszemélyzete végez el, a biztosító finanszírozásával.

A tartózkodással járó fürdókúrák rehabilitációs vagy prevenciós céllal vehetőek igénybe, hasonlóan a német rendszerhez. A kúrák igénybevételéhez kérelmet kell benyújtani az illetékes társadalombiztosítási intézménynek (egészségbiztosítónak, nyugdíjbiztosítónak, balesetbiztosítónak). A kérelemhez csatolni kell az orvosi véleményt, a terápiás szükséglet igazolását. A kórházi tartózkodást is követheti gyógyfürdőkúra, ebben az esetben a kórház a kezdeményező, amely a rehabilitációt előírja. Kétféle finanszírozási kérelem adható be:

- bentlakásos tartózkodás gyógyászati létesítményekben, a társadalombiztosítás saját intézményeiben vagy szerződött intézményekben, amikor a biztosító közvetlenül a szolgáltatást nyújtó intézményt finanszírozza;

\footnotetext{
A Cseh Köztársaság 48/1997 törvénye a népegészségbiztositásról. https://
} www.zakonyprolidi.cz/cs/1997-48, Letöltve: 2018. augusztus 12.
- a gyógyfürdókúra és a tartózkodás költségeihez történó hozzájárulás, ebben az esetben a kérelmező maga fizet az ellátásért, a biztosító utólag téríti meg a költségeit.

A biztosítók nem kötelesek finanszírozni a kúrát, a beteg kérelme elutasítható vagy részlegesen támogatható. Ha a kérelmet pozitívan bírálják el, akkor a költségek nagyobb részét fedezi a biztosító, ám jövedelemi helyzetétől függóen a beteg önrész fizetésére kötelezhető.

Egy fürdőkúra általában 22 napos, ami orvosi javaslatra meghosszabbítható. A biztosított nem jogosult a gyógyfürdő kiválasztására, de a biztosító igyekszik figyelembe venni a beteg kérését. Ha a betegség Ausztriában nem kezelhető megfelelő hatékonysággal, a társadalombiztosítás külföldön is finanszírozhat gyógykúrát.

Fürdőkúra ötévente kétszer vehetô igénybe. Kivételt jelent, ha a beteg bizonyos kórképekről speciális orvosi igazolást kap, ilyen esetben gyakrabban is igényelhető.. Ha orvosilag indokolt, a biztosító a kísérôszemély költségeit is megtérítheti. $^{8}$

\subsection{ROMÁNIA}

A román finanszírozási rendszer hasonlít a magyarra, de vannak az osztrák, a német és a cseh rendszerhez hasonló elemei is. A kezeléseket járóbeteg-ellátásban vagy tartózkodással járó gyógykúrák formájában lehet igénybe venni.

A járóbeteg-ellátásban a biztosítottak évente legfeljebb két kúrára jogosultak (lásd a magyar rendszert), a biztosító a kúra során igénybe vett kezeléseket teljes egészében téríti. Egy gyógykúra átlagosan 10 napos, 4 kezelés/nap intenzitással. A balneoterápiás kezeléseket is nyújtó gyógyfürdőkben a négy kezelésből kettő természetes gyógytényezővel történik. ${ }^{9}$

Az ellátás másik formája a klinikai/szanatóriumi ellátás. A szanatóriumokban 14-21 napos orvosi rehabilitációs kezelést nyújtanak. Az ellátás a háziorvosok, a szak- és a kórházi orvosok által kiállított beutaló alapján történik, amely tartalmazza a kúra hosszát és a kezelés formáit.

Az ellátást egyetlen összefüggő kúraként lehet alkalmazni, mely során legfeljebb 4 kezelés/nap vehető igénybe. A kúra 14 napnál lehet rövidebb,

\footnotetext{
${ }^{8}$ Öffentliches Gesundheitsportal Österreich: Rehabilitations- und Kuraufenthalt. https://www.gesundheit.gv.at/gesundheitssystem/leistungen/ krankenhausaufenthalt/kuraufenthalt, Letöltve: 2018. augusztus 12.

${ }^{9}$ Casa de Asigurari de Sanatate a Municipiului Bucuresti: Serviciile medicale de recuperare, medicina fizica si balneologie. https://casmb.ro/asigurati_servicii_medicale_de_recuperare_medicina_fizica_si_balneologie. php, Letöltve: 2018. augusztus 12
} 
Múhely

de a 21 napot meghaladó kúra költségeit a biztosítottnak kell viselni. ${ }^{10}$

\section{A fürdógyógyászat közfinanszíro- zásának magyar rendszere}

A szolgáltatók által nyújtható támogatott fürdőgyógyászati ellátásokat az 5/2004. (XI.19.) EüM rendelet határozza meg. A rendelet jelenleg kilenc fürdőgyógyászati ellátást, egy egyéb rehabilitációs célú gyógyászati ellátást, valamint egy egyéb természetes gyógytényezőn alapuló gyógyászati ellátást tartalmaz (2. táblázat). A kezeléseket a kezelőorvos (jellemzően reumatológus szakorvos) írja fel. Egy kúra keretén belül:

- a 01-08 kóddal jelzett fürdógyógyászati ellátások közül legfeljebb négy különböző rendelhetó egy kúra során, kezelésenként 15-15 alkalomra (azaz a kúra összesen 15, 30, 45 vagy 60 kezelésből állhat);

- a 09 Komplex fürdőgyógyászati ellátás amely alkalmanként szintén négy különféle kezelést tartalmazhat - legfeljebb 15 alkalomra, baleseti vagy mútéti utókezelés esetén legfeljebb 20 alkalomra, rendelhetó (azaz a kezelések együttes száma 60 vagy 80 lehet). A komplex fürdőgyógyászati ellátás a rendelet 4. mellékletében nevesített további, a balneoterápiás kezeléseket kiegészítő 13 fizikoterápiás kezelésfajtát is tartalmazhat (egyéni gyógytorna, csoportos gyógytorna, ultrahang kezelés, magnetoterápia, fototerápia, kryoterápia $\mathrm{stb}$.).

2. táblázat

Országos minôsítésú gyógyfürdők támogatási összegei kezelésenként

\begin{tabular}{|l|l|l|l|}
\hline $\begin{array}{l}\text { Kezelés } \\
\text { megnevezése }\end{array}$ & $\begin{array}{l}\text { Közfinanszirozás } \\
\text { alapját képezó ár } \\
\text { (ÁFA nélkül, Ft) }\end{array}$ & $\begin{array}{l}\text { TB } \\
\text { támogatás } \\
\text { mértéke } \\
(\%)\end{array}$ & $\begin{array}{l}\text { TB } \\
\text { támogatás } \\
\text { ÁFA } \\
\text { nélküli } \\
\text { összege } \\
(\text { Ft })\end{array}$ \\
\hline $\begin{array}{l}\text { 01 Gyógyvizes } \\
\text { gyógymedence } \\
\text { (ideértve a hévízi } \\
\text { tófürdőt is) }\end{array}$ & 548 & 50 & 274 \\
\hline $\begin{array}{l}\text { 02 Gyógyvizes } \\
\text { kádfürdő }\end{array}$ & 649 & 85 & 552 \\
\hline
\end{tabular}

\footnotetext{
${ }^{10}$ Casa Națională de Asigurări de Sănătate: Pachetul de servicii medicale de bază în asistența medicală de Recuperare medicală, în sanatorii, inclusiv sanatorii balneare şi Preventorii. http://www.cnas.ro/page/pachetul-de-servicii-medicala-de-baza-in-asistenta-medicala-de-reabilitare-medicala-in-sanatorii-balneare-si-recuperare-medicala-in-alte-sanatorii-i-preventorii.html, Letöltve: 2018. augusztus 12
}

\begin{tabular}{|l|l|l|l|}
\hline 03 Iszappakolás & 1233 & fix & 948 \\
\hline 04 Súlyfürdő & 748 & fix & 561 \\
\hline $\begin{array}{l}\text { 05 Szénsavas } \\
\text { fürdō }\end{array}$ & 1059 & fix & 786 \\
\hline $\begin{array}{l}\text { 06 Orvosi } \\
\text { gyógymasszázs }\end{array}$ & 932 & fix & 580 \\
\hline $\begin{array}{l}\text { 07 Víz alatti } \\
\text { vízsugármasszázs }\end{array}$ & 1018 & fix & 765 \\
\hline $\begin{array}{l}\text { 08 Víz alatti } \\
\text { csoportos } \\
\text { gyógytorna }\end{array}$ & 714 & 85 & 607 \\
\hline $\begin{array}{l}\text { 09 Komplex } \\
\text { fürdógyógyászati } \\
\text { ellátás }\end{array}$ & 2622 & 85 & 2229 \\
\hline $\begin{array}{l}\text { 10 18 éves kor } \\
\text { alatti csoportos } \\
\text { gyógyúszás (egyéb } \\
\text { gyógyászati } \\
\text { ellátásként } \\
\text { nevesítve) }\end{array}$ & 744 & 100 & 744 \\
\hline $\begin{array}{l}\text { 11 Szén-dioxid } \\
\text { gyógygázfürdó } \\
\text { (egyéb természetes } \\
\text { gyógytényezôn } \\
\text { alapuló } \\
\text { gyógyászati } \\
\text { ellátásként } \\
\text { nevesítve) }\end{array}$ & 1200 & 85 & 1020 \\
\hline
\end{tabular}

Forrás: Az 5/2004. (XI. 19.) EüM rendelet 8. számú melléklete

Az ellátást elrendelő orvos indokolt esetben a kúrát alkotó kezelések számát az előzőtől eltéróen is meghatározhatja, de az egyes ellátásfajták tekintetében hatnál kevesebb vagy húsznál több alkalomra nem írható elő kezelés (NEAK TÁJÉKOZTATÓ A GYÓGYFÜRDŐ ELLÁTÁSRÓL).

Az 5/2004. (XI.19.) EüM rendelet szerinti ellátásokra vonatkozóan az Egészségbiztosítási Alapban önálló költségvetési sor szerepel „Gyógyfürdő és egyéb gyógyászati ellátás támogatása" címmel. Ez a gyógyfürdőkassza, amely keret 2013-tól évi 4,2-4,3 milliárd forint között alakult.

Az 5/2004. (XI.19.) EüM rendelet a beutalóval igénybe vehető gyógyfürdőellátások támogatását százalékos mértékben és fix összegben állapítja meg. A támogatás alapja a NEAK által elfogadott ár, ami a közfinanszírozás alapját képezó ár (2. táblázat).

Az egyes elvégzett kezelések után a rendelet hatálya alá tartozó szolgáltatók kiegészítő térítési díjat kérhetnek a beutalóval érkező betegektől. Kezelésenként általában néhány száz forintról van szó (szolgáltatótól függóen 300-800Ft/kezelés), kivéve a 09 Komplex fürdőgyógyászati ellátást, amely több önálló kezelést tartalmaz, így a betegek által fizetendő kiegészítô térítési díj is magasabb. 
A közfinanszírozás alapjául szolgáló ár és a támogatás mértéke időről időre felülvizsgálatra kerül. A legutolsó ártárgyalásra 2011-ben került sor. Az azóta eltelt időszakban az egészségügyben a bérek közel 90\%-kal nőttek, miközben a támogatások valorizálása nem történt meg, így a fürdőgyógyászatok jövedelmezősége jelentősen romlott.

\subsection{FÜRDŐGYÓGYÁSZATI ELLÁTÁSOK FINANSZÍROZÁSA JÁRÓBETEG SZAKELLÁTÁSBAN}

A fürdőgyógyászati ellátások a járóbeteg szakellátásban is finanszírozhatók. A finanszírozás alapja a 9/2012. (II.28.) NEFMI rendeletben ${ }^{11}$ rögzített, az egyes járóbeteg szakellátásokhoz tartozó teljesítménypontszám. Ez a pontszám a járóbeteg szakellátás teljesítményegységének forintértékével kerül átszámításra (2018-ban 1,98Ft/pont), majd folyósításra az egészségügyi intézményeknek (3. táblázat). (Járóbeteg szakellátásban a finanszírozható balneoterápiás és fizikoterápiás kezelések köre szélesebb, az 5/2004. (XI.19.) EüM rendeletben felsoroltaknál többféle ellátástípus támogatható.)

3. táblázat

OENO $^{12}$ kódok táblázata, egyes kezelések pontszáma és finanszírozása a járóbeteg szakellátásban (Törzslista részlete a 15/2018. (VI.28.) EMMI rendelet ${ }^{13}$ alapján)

\begin{tabular}{|l|l|l|l|}
\hline OENO kód & \multicolumn{1}{|c|}{ Kezelés } & Pontérték & $\begin{array}{l}\text { Finanszírozás } \\
(1,98 \mathrm{Ft} / \text { pont })\end{array}$ \\
\hline 94880 & Medencefürdő & 145 & $287,1 \mathrm{Ft}$ \\
\hline 94881 & Kádfürdő & 366 & $724,7 \mathrm{Ft}$ \\
\hline $9488 \mathrm{H}$ & $\begin{array}{l}\text { Iszappakolás az } \\
\text { egész testre }\end{array}$ & 595 & $1178,1 \mathrm{Ft}$ \\
\hline 94883 & $\begin{array}{l}\text { Súlyfürdô nyaki } \\
\text { függesztéssel }\end{array}$ & 353 & $698,9 \mathrm{Ft}$ \\
\hline 94882 & $\begin{array}{l}\text { Szénsavfürdő } \\
94712\end{array}$ & 574 & $1136,5 \mathrm{Ft}$ \\
\hline $9488 \mathrm{G}$ & $\begin{array}{l}\text { Vízszalatti vízsugár- } \\
\text { masszázs }\end{array}$ & 347 & $687,1 \mathrm{Ft}$ \\
\hline 55513 & $\begin{array}{l}\text { Víz alatti torna } \\
\text { (csoportos) }\end{array}$ & 115 & $227,7 \mathrm{Ft}$ \\
\hline
\end{tabular}

Forrás: Nemzeti Egészségbiztosítási Alapkezelő (NEAK) http://neak.gov. hu/felso_menu/szakmai_oldalak/gyogyito_megeleozo_ellatas/szabalykonyvek/jaro.html, Letöltve: 2018 augusztus 12.

\footnotetext{
${ }^{11}$ https://www.hbcs.hu/uploads/jogszabaly/1406/fajlok/20130101_tol_hatalyos_9_2012_NEFMIr.pdf

${ }^{12}$ Orvosi Eljárások Nemzetközi Osztályozása

${ }^{13}$ https://www.hbcs.hu/uploads/jogszabaly/2738/fajlok/15_2018_EMMI_ rendelet honlapra.pdf
}

A járóbeteg szakellátásban a kezelések finanszírozása az 5/2004. (XI.19.) EüM rendeletben meghatározottakhoz hasonló, egyes kezelések esetében valamivel kedvezőbb (például kádfürdő, iszappakolás, súlyfürdő), más kezelések esetében kedvezótlenebb (például masszázs, víz alatti torna). Érdemes megjegyezni, hogy a járóbeteg szakellátás finanszírozása kissé javult az elmúlt években. A teljesítményegység forintértéke 2016-ban 1,80Ft, 2017-ben 1,85 Ft, 2018-ban 1,98 Ft volt. Járóbeteg szakellátásban azonban a biztosítottaktól nem szedhető kiegészítő térítési díj .

\subsection{FÜRDŐGYÓGYÁSZATI ELLÁTÁSOK FINANSZÍROZÁSA A FEKVŐBETEG SZAKELLÁTÁSBAN}

Az egészségügyi ellátórendszerben a fekvőbeteg szakellátás keretében finanszírozott rehabilitációs ellátások során számos olyan kezelést nyújtanak, amelyek a fürdőgyógyászat körébe tartoznak. Ebben az esetben a szolgáltatók (főként kórházak) a rehabilitációra biztosított napidíjas finanszírozásból gazdálkodják ki a balneo- és fizikoterápiás kezelések költségeit. A napidíj összege: krónikus alapdij $^{14}$ rehabilitációs szorzóval növelve.

A rehabilitáció keretében lehetőség van úgynevezett nappali kórházi ellátásra is, amikor a beteg az éjszakát nem az intézményben tölti. Nappali kórházi ellátás során az egészségügyi szolgáltatók a hatályos szabályozás szerint az alapdíj 70\%-ára jogosultak, ha napi legalább 6 órában nyújtanak ellátást. Rehabilitációs kapacitásokkal (ágyakkal) elsősorban a fürdókórházak rendelkeznek (például a harkányi vagy a hévízi fürdőkórház), amelyek fürdőgyógyászati ellátások nyújtására specializálódott egészségügyi intézmények. A gyógyfürdőknek azonban nincsenek rehabilitációs kapacitásai, mivel nem nyújtanak fekvőbeteg szakellátást. Egyegy kivétellel (lásd például a Lukács Gyógyfürdő Szent Lukács Nappali Kórházát) nem rendelkeznek nappali kórházzal sem.

A tárgyalt országok fürdőgyógyászati finanszírozási rendszerének főbb jegyeit az 1. ábrában foglaltuk össze.

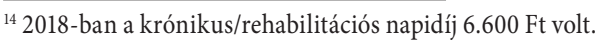


Fürdőgyógyászati szolgáltatások közfinanszírozása Európa öt országában és Magyarországon (összefoglalás)

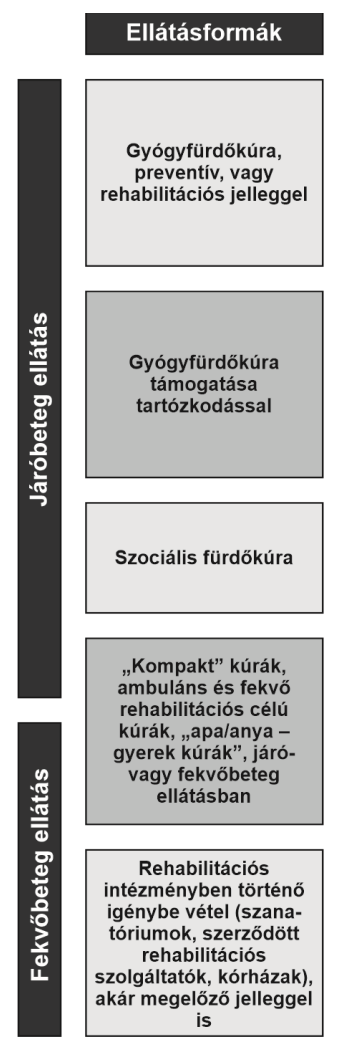

Forrás: saját szerkesztés
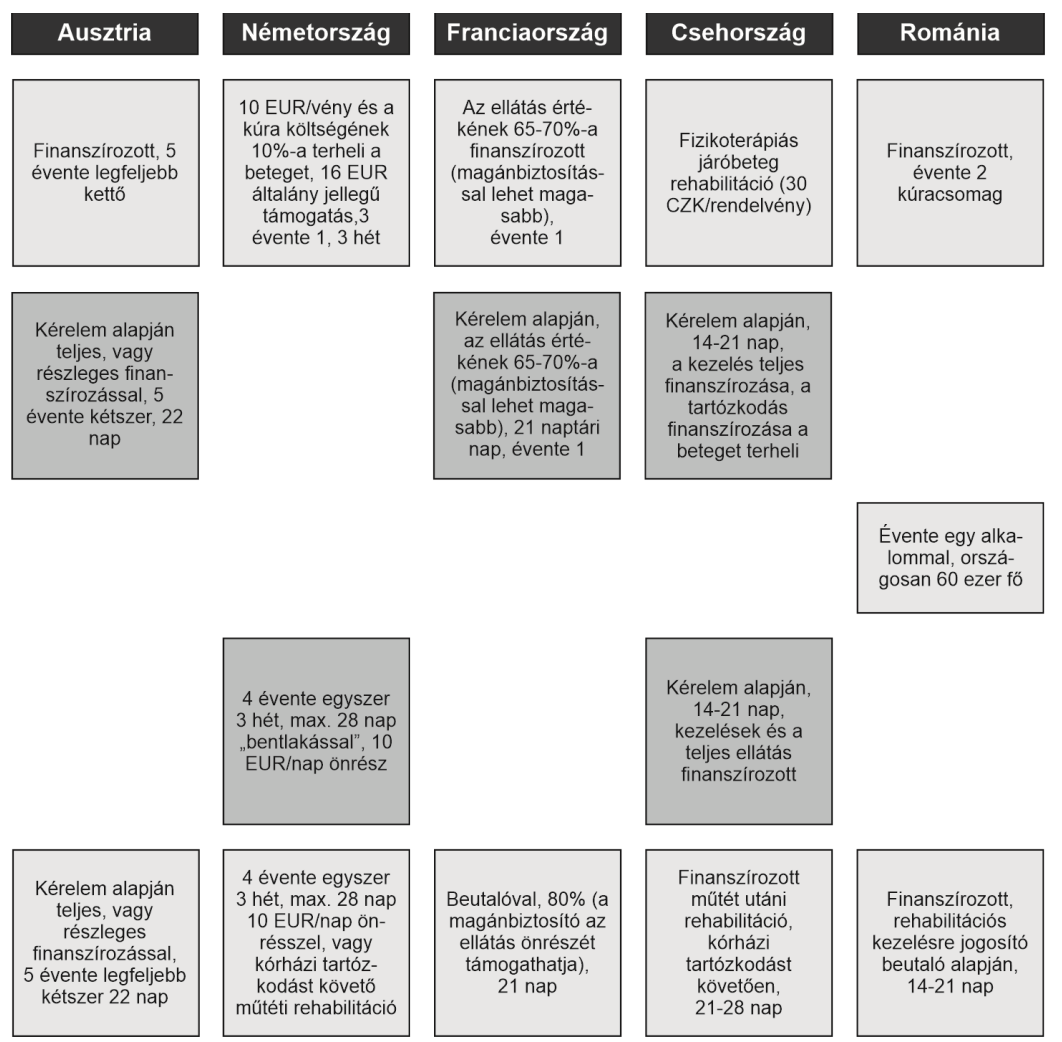

Magyarország

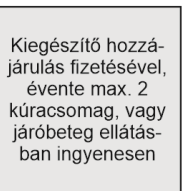

ban ingyenesen

\section{Az európai és a magyar finanszí- rozás összehasonlítása implikációk a magyar gyógyfürdó ellátások finan- szirozása tekintetében}

A vizsgált országokkal összehasonlítva Magyarországon a kettôs finanszírozás jellemző. A szolgáltatónak akár kétféle szerződése is lehet, hisz egyes gyógyfürdőknek az 5/2004. (XI.19.) EüM rendelet szerinti finanszírozás mellett járóbeteg szakellátás finanszírozására is van szerzódése. Ezek a gyógyfürdók szakorvosi vizsgálatokat is el tudnak számolni az Egészégbiztosítási Alap terhére, szemben a szolgáltatók többségével, akik csak az 5/2004. (XI.19.) EüM rendelet szerinti támogatásra jogosultak. Utóbbiaknak a szakorvosok (például reumatológusok) finanszírozását (amely a 09 Komplex fürdőgyógyászati ellátás nyújtása esetén előírás) a kezelések bevételeiból kell kitermelniük, vagy térítési díjat kell kérniük a betegektől a szakorvosi vizsgálatokért. Amikor a gyógyfürdók vezetői körében felvetettük, hogy az ilyen jellegú anomáliák miatt inkább egységes, az egészségügyre általánosan jellemzó finanszírozást kellene alkalmazni, ami a járóbeteg szakellátás finanszírozási rendszere lenne, nem támogatták az ötletet. Ennek oka az, hogy a járóbeteg szakellátás finanszírozási mértékei nem fedezik a szolgáltatás nyújtásának önköltségét, önrészt pedig nem kérhetnek a betegektól, míg az 5/2004. (XI.19.) EüM rendelet alkalmazása esetén van valamennyi mozgásterük a térítési díjak megállapítása során.

A betegek a kezelésekért hozzájárulást fizetnek Franciaországban és Németországban, valamint kisebb mértékben Csehországban. Magyarországon azonban a gyógyfürdókben igénybe vett kezelések betegek által fizetett önrésze akár magasabb is lehet, mint az a támogatás, amit a kezelések után a NEAK folyósít a szolgáltatónak. Egy 60 kezelésből álló kúra során a beteg által összesen kifizetett térítési díj összege meghaladhatja akár a 30000 forintot is, attól függően, hogy melyik gyógyfürdőben és mikor történnek a kezelések. A magyar nyugdíjasok esetében a térítési díj nagysága az egyik legfontosabb versenytényezó a gyógyfürdók kiválasztásában.

A térítési díj alapú verseny esetenként igen éles, ahogy azt Szegeden az Anna Fürdó és a 
Napfényfürdő Aquapolis fürdőgyógyászata esetében tapasztaltuk. Az egymáshoz közel elhelyezkedő szolgáltatók közül a betegek elsősorban ahhoz mennek, ahol alacsonyabb a betegek által fizetett önrész. A Napfényfürdő Aquapolis a jobb minőségú infrastrukturális háttér által támogatott szolgáltatásait magasabb önrész mellett nyújtja, így az Anna Fürdőben jelentkezik a szegedi fürdógyógyászati teljesítmény döntő része, becslésünk szerint $70-75 \%$-a.

Ezt támasztja alá az egyik legnagyobb gyógyfürdő megfigyelése is, amely szerint a beutalóval érkező, jellemzően nyugdíjas betegek az önrészt esetenként olyan magasnak érzékelik, hogy inkább lemondanak egyes kezelésekról.

További eltérés a nyugati modellekkel összehasonlítva, hogy a magyar rendszerben - hacsak nem rehabilitációs célú fekvőbeteg szakellátásról van szó - a beteg tartózkodásának költségeihez az Egészégbiztosítási Alap nem nyújt támogatást, ugyanakkor évente akár két alkalommal is támogatja a gyógyfürdő kezeléseket. Ez sok tekintetben érthetó is: a szúkös forrásokat a tartalomra (a kezelésekre) fordítja az egészségügyi rendszer, nem hotelszolgáltatások finanszírozására. Azonban, ha csak az adott szolgáltatónál elérhetô gyógytényezóért utazni szükséges, felmerül a kérdés, hogy az utazás és az ott tartózkodás költségeit indokolt esetben valamilyen mértékben érdemes lenne támogatni, ezzel is csökkentve az országon belüli hozzáférési nehézségeket. A fekvőbeteg szakellátásban igénybe vehető (azaz kórházi tartózkodással járó) rehabilitáció nem helyettesíti a tartózkodással járó gyógykúrákat, amelyek nyugaton akár prevenciós jellegúek is lehetnek. Más kérdés, hogy a tartózkodás támogatása egyetlen vizsgált országban sem automatikus, és az igénybevételek száma is korlátozott, például Németországban, Ausztriában 3-4 évente egy alkalommal támogatnak kúrát a biztosítók. A beutalóval érkezô magyar beteg a hatékony kúrahossznak megfelelő tartózkodást általában nem képes maga finanszírozni. Egy kúra optimális esetben 14-21 nap, ám a beutalóval érkezô, jellemzően nyugdíjas beteg gyakran csak 4-5 napot tartózkodik a gyógyhelyen. A legtöbben még ennyit sem, mivel 65 év felett a közösségi közlekedés igénybevétele ingyenes, így a betegek reggel érkeznek a kezelésekre, este pedig hazautaznak.

Az áttanulmányozott szekunder információk alapján úgy túnik, hogy a nyugat-európai országok fürdőgyógyászatában jobban érvényesül a betegségek kezelésére leginkább megfelelő szolgáltató kiválasztására irányuló szemlélet, továbbá jellemzó a szolgáltatók szakosodása. A magyar szabályozás is konkrét kezeléseket javasol az egyes kórképekhez (lásd az 5/2004. (XI.19.) EüM rendelet 5. mellékletét), ám a szakosodás csak kevés szolgáltató esetében figyelhetó meg. Az orvosi kutatások, amelyek az evidence-based terápiákat alapoznák meg, ritkák a gyógyfürdőkben, mivel a jelenlegi finanszírozási rendszernek nincs ösztönző hatása.

Interjúalanyaink arra is rámutattak, hogy egymással versenyző kezelések, például egyre hatékonyabb gyógyszeres terápiák, kevésbé invazív beavatkozások (egynapos sebészet) jelentek meg, amelyekkel szemben teret veszíthet a hagyományos gyógytényezőkre épülő fürdőgyógyászat. A fiatalabb generációk számára (tágabban értelmezve a 25-54 éves korosztály), akik a prevenció célcsoportjai lehetnének, a gyógyfürdők általában nem vonzóak, az idősebbek körében még mindig népszerú fürdőgyógyászati kezelésekről nem is hallottak. A fürdőgyógyászat két-három hetes hatékony kezelési időtartama napjaink felgyorsult életritmusa mellett kevésbé versenyképes számukra. Két-három hét gyógyhelyi tartózkodásra egy átlagos munkavállalónak nincs ideje. Emiatt a természetes gyógytényezók, amelyek lassabban fejtik ki hatásukat, egyre inkább meghaladottá válnak a betegek szemében.

Ahogy az interjúkból is kiderült, a nyugati vendégek, különösen a német gyógyturisták, akik a fürdőgyógyászatok legfontosabb célcsoportját képviselték, egyre inkább elmaradnak. Ennek nemcsak a változó utazási preferenciák, a gyorsan fejlődő egészségügyi ellátás, az elégtelen egészségturisztikai infrastruktúra és marketing az oka, hanem az erősödő konkurencia is. A magyar szolgáltatók által nyújtott kezelések Nyugat-Európában, a beteg otthonában is igénybe vehetőek a hazai egészségbiztosító finanszírozásával, gyakran jobb minóségben, mint külföldön (Magyarországon). Erre is reagálva, a következó években megvalósuló nagyszabású gyógyhelyi fejlesztések célja a magyar fürdőhelyek, gyógyfürdők versenyképességének növelése.

Ahogy a fentiekből kiderült, a magyar fürdőgyógyászatban és az erre épülő egészségturizmusban rejlő lehetőségek kiaknázatlanok. Ennek egyik fontos tényezője a közfinanszírozás változtatásának lehetôsége, amely keretében érdemes rendszeresen felülvizsgálni a fürdőgyógyászat közfinanszírozás, amelynek mértékét és módjait felül kell vizsgálni, beleértve a merev, kasszánként elkülönülő finanszírozási szabályozást is. Ha a hazai betegek kezelése alulfinanszírozott rendszerben, nem megfelelően ösztönző struktúrában történik, nem jön létre versenyképes egészségturisztikai kínálat. Hatékony és vonzó egészségturisztikai kínálat, turisztikai termék a közfinanszírozott ellátásokra épül. Ha a magyar beteg ellátása eredményes 
Múhely

és hatékony, akkor erre felépíthető az egészségturisztikai kínálat is. Vizsgálatunk arra is rámutat, hogy a finanszírozási kérdések rendezése során nagyobb figyelmet szükséges fordítani a természetes gyógytényezókön alapuló fürdőgyógyászati szolgáltatási kínálat és a kezelések, ellátások megújítására. Ahogy a vizsgált országok példái mutatják, fejleszteni kell a prevenciós és rekreációs kínálatot, amely a fiatalabb, egészségtudatos korosztályokat vonzaná, másrészt egyes betegségcsoportokra fókuszáló, klinikai vizsgálatokkal is alátámasztott hatásosságú terápiás és rehabilitációs célú komplex csomagok kialakítására van szükség.

\section{Köszönetnyilvánítás}

Ezúton is köszönjük a Magyar Fürdőszövetségnek a tanulmány elkészítéséhez nyújtott támogatását.

\section{Felhasznált irodalom}

A Magyar Fürdőszövetség helyzetértékelése és javaslatai a magyar egészségturizmus versenyképességének javítása érdekében. Magyar Fürdőszövetség. Budapest, 2010.

CONNELL, J. (2006): Medical tourism: Sea, sun, sand and... surgery. Tourism Management. 27(6). pp. 1093-1100.

HALL, C. M. (2012): Medical and health tourism: The development and implications of medical mobility. In: Hall, C. M. (ed): Medical Tourism: The Ethics Regulation, and Marketing of Health Mobility. Routledge, London. pp. 19-44.
JANDALA CS. - SÁNDOR T. - GONDOS B. (2010): Az egészségturizmus a turizmuspolitika fókuszában - A fürdőkultúra szerepe a turisztikai termékfejlesztésben. Turizmus Bulletin. 14(4). pp. 19-28.

KINCSES GY. (2010): Az egészségügyi turizmus helyzete, jövőképe, szükséges fejlesztési irányai. IME - Interdiszciplináris Magyar Egészségügy. 9(6). pp. 5-12.

MICHALKÓ G. - RÁTZ T. (2011): Egészségturizmus és életminôség Magyarországon: Fejezetek az egészség, az utazás és a (jól)lét magyarországi összefüggéseirôl. MTA Földrajztudományi Kutatóintézet, Budapest.

NAGY Z. - SZÉP T. (2011): Az egészségturizmus szerepe az Észak-magyarországi régió turisztikai kínálatában. A Miskolci Egyetem közleményei. A sorozat, Bányászat. 81. pp. 211219.

SMITH, M. K. - PUCZKÓ, L. (2009): Health and Wellness Tourism. Elsevier/ButterworthHeinemann, Oxford.

\section{Internetes források}

5/2004. (XI. 19.) EüM rendelet az orvosi rehabilitáció céljából társadalombiztositási támogatással igénybe vehetố gyógyászati ellátásokról. https://net.jogtar. hu/jogszabaly?\%20docid=A0400005.EUM, Letöltve: 2018. augusztus 12.

NEAK tájékoztatóa gyógyfürdó ellátásról. http://www. neak.gov.hu/felso_menu/lakossagnak/ellatas_ magyarorszagon/gyogyszer_segedeszkoz_ gyogyfuro_tamogatas/gyogyfurdo, Letöltve: 2018. augusztus 12 . 